\title{
PROFILE OF MICROORGANISMS ATTRIBUTABLE TO DERMATOPHYTOSIS AMONG PATIENTS AT SULTAN AGUNG ISLAMIC HOSPITAL, SEMARANG
}

\author{
Rahayu1), Masfiyah'), Hesti Wahyuningsih K²) \\ 1)Department of Clinical Microbiology, Faculty of Medicine, \\ Universitas Islam Sultan Agung \\ 2)Department of Skin and Genital Disease, Faculty of Medicine, \\ Universitas Islam Sultan Agung
}

\begin{abstract}
Background: Dermatophytosis, also known as ringworm, is a fungal infection of the skin. Typically the skin disease results in a red, itchy, scaly, circular rash. Hair loss may occur in the area affected. Symptoms begin four to fourteen days after exposure. Multiple areas can be affected at a given time. About 40 types of fungi can cause ringworm. They typically come from Trichophyton sp., Microsporum sp., or Epidermophyton sp. This study aimed to describe the profile of microorganisms attributable to dermatophytosis among patients at Sultan Agung Islamic Hospital, Semarang.

Subjects and method: This was a descriptive cross sectional study conducted at Sultan Agung Islamic Hospital, from January to December 2016. A sample of patients with dermatophytosis was selected for this study. The data were collected from the medical record and described in percent.

Results: As much as 53\% of patients with dermatophytosis were female. Dermatophytosis patients were diagnosed as Tinea corporis (35\%), Tinea capitis (29\%), Tinea pedis (21\%), Tinea cruris (12\%), and Tinea unguium (3\%). Dermatophyte fungi were Microsporum canis (32\%), Trichophyton mentagrophytes (18\%), Microsporum audiounii (6\%), Trichophyton rubrum (3\%), and Trichophyton tonsurans (3\%).
\end{abstract}

Conclusion: Microsporum canis is the most common fungi that causes dermatophytosis.

Keywords: dermatophytosis, fungi

\section{Correspondence:}

Rahayu. Department of Clinical Microbiology, Faculty of Medicine, Universitas Islam Sultan Agung, Semarang, Central Java. Email: rahayu.md5059@gmail.com. Mobile: 081326490064. 